\title{
"The Irrepressible Conflict of 1861" The Letters of Samuel Ryan Curtis
}

\author{
EDITED BY KENNETH E. COLTON
}

The letters published here of Samuel Ryan Curtis, soldier, engineer, and Congressman, begin in January, 1861, two months after the fateful presidential election of November 6, 1860, which sent Abraham Lincoln to the White House a minority president and which set the country reeling, amid visible signs of preparation, toward an "irrepressible conflict."1

The Curtis letters commence in the midst of strenuous last hour efforts to find some means of compromise whereby the Union might be preserved. The debates were bitter; ominous were the declarations both in and out of Congress, North and South, that nothing could save the Union. Despair and inaction in high places and low, in Washington and in the states, were everywhere to be seen and heard.

The art of successful compromise which had won the victories of 1820,1832 , and 1850 , appeared lost. Possibly even Henry Clay might not have exercised his magic in 1861, a magic which had produced the Missouri Compromise, the Tariff of 1833, and the Compromise of 1850 . A Senatorial Committee of Thirteen and a House Committee of Thirty-three, appointed in the first weeks of December, 1860, were in January discovering the difficulties of reconciling intransigient principles. The rock upon which all efforts foundered was the Northern insistence upon "no extension of slavery into the territories," and the Southern demand that this right be granted.

The Buchanan administration could offer no leadership to a country distraught; harried by hesitancy, uncertainty, and the southern dominance of its party, split and divided within itself, it watched in impotence a

1The phrase "irrepressible conflict" originated in a speech of William H. Seward at Rochester, N. Y., Oct. 25, 1858. Dictionary of American History, 3, 160. 
republic in sore travail. ${ }^{2}$ The country itself, torn by conflicting desires for Union, compromise, and the support of "principles," presented a sorry picture of disunity in the face of a gathering storm. Events were in the laps of the gods.

Written to his wife Belinda, at their home in Keokuk where the family had lived for the past seven years, the letters of "Col. Curtis" as he was known in Keokuk, reflect the uneasiness of a Washington familiar with the threats of Southern firebrands and the prediction of Confederate Secretary of War Leroy Walker. ${ }^{3}$ They reflect a national capitol filled with the turmoil of the rush of patronage seekers, anxious to share in the spoils and rewards of the first administration of a new party, they are filled with the uneasiness of a Washington surrounded by a wavering Virginia and an uncertain Maryland. In these letters echoes the approach of the call to arms.

The Curtis correspondence in many respects but confirm impressions well known to students of the Civil War from the letters and diaries of other public men, of Seward, Weed, Welles, and Browning, to mention a few. These are significant letters, however, because they are the opinions of a western man, representing the frontier state of Iowa. They reflect the frank views, hasty and considered alike, of a man educated in the United States Military Academy at West Point, class of 1831, of a man who had spent a year on the western military posts, had served as a Colonel in the Mexican War with the Third Ohio Infantry, who had struggled with problems of highway, waterway, and rail transportation and navigation in Ohio, Iowa, and Missouri, of a man who had practiced the professions of arms, engineering, and the law. ${ }^{4}$

2John B. Floyd, governor of Virginia, 1849-1852, secretary of war in eabinet of James Buchanan, 1859-1860, opposed to the reenforcement of Major Robert Anderson at Charleston, resigned December 29, 1860. Served in the Confederate forces after the outbreak of war, died in 1863, after attaining the rank of Major General. Cf. Dictionary of American Biography.

${ }^{3}$ Leroy Pope Walker, a leading secessionist Democrat of Alabama, was appointed Seeretary of War by Jefferson Davis February 21, 1861, a position he resigned in September due to his feeling of insdequate experience for the post. $D$. A. B., 19, 351. Walker had shouted that the Confederate forces would be in Washington by May 1, ef Rhodes, History of the United States, 3, 361.

isee D. A. B., 1, 619-620; Iove Historical Record, 3, 561-565; Stewart, Iovoa Colonels and Regiments, etc., 1865, pp. 35-50. Curtis was deseribed by Hawkins Taylor, one of his Keokuk friends as "of pure habits and full of self-confidence, of an amiable disposition. Ambitious, because he felt that he was competent to 
Samuel R. Curtis, at fifty-six, a tall man "of commanding appearance in size and deportment . . . full of selfconfidence, of an amiable disposition" was serving the last months of his second term as the first Republican representative from the first Iowa congressional district. Active in Congress on the Military Affairs Committee of the House and in proposals for a western Pacific railroad, Curtis was anxiously awaiting the inauguration of Abraham Lincoln in March, when he would begin his third term as Lincoln began his first in the White House.

A devoted husband and father, besides his wife Belinda, four children comprised the family. The eldest, Henry, was engaged in banking in Keokuk five years before; in 1861 , at the age of 24 , he was located in the Territory of Nebraska, presumably in Omaha. Three years later he was to lose his life in a skirmish with Southern forces in the State of Kansas. Samuel, the second son, a year younger than Henry, had left the family home to try his fortunes in the Territory of Colorado. Sadie, a graceful nineteen in 1861, as the eldest daughter kept quarters for her father while he attended sessions in Washington during the months recorded below. The baby of the family was Carrie, a child of eight in 1861, the "Caddie" so frequently mentioned in the father's letters to his wife. ${ }^{5}$

My dear Wife

H R Washington Jany 9. 1861

Your letter of the $2 \mathrm{~d}$ and one from Goodi- on the subject of changing our household arrangements were received last night. I am inclined to think we had better give up housekeeping, some time soon, but I dislike to do so without some further reflection: for I have a longing anxiety to unite our dear family with you at our quiet fireside in March and if then the troublesome times permit, allow us a few weeks or months of family home enjoyment.

I will not precipitate a determination. We need not be in great haste. I presume Goodrill [?] will not be required to move hastily.

fill any position, without any of the qualities to capture the masses." Iowa Historical Record, supra.

${ }^{5}$ Cf. Iowa State Census, 1856, Lee County, (Vol. 52). 
Although things look quite cheerless [?] in many respects, we are not in desparate straits just yet and we need not be in great haste.

Goodril proposes that he take the house and in consideration board you and Carrie. This does not seem to me a safe arrangement for us. You may or may not desire to remain there. If I am to be here most of the time to attend called cessions as now seems probable you would probably prefer to be nearer to me and I should prefer to have you. I would of course prefer that Goodril should have the house and furniture, but is he so settled now as to feel certain he will remain in Keokuk. Hard times are down on all of us and we must arrange our domacils [sic] to suit the revolutionary times that now seems to embarrass all matters of business and may influence the peace and quiet of different localities.

We have got through the Committee of $33^{6}$ and the Chairman Mr. Corwin ${ }^{7}$ is now writing out his report. Our recommendations are only explanatory of our views of Southern rights under the Constitution with provisions to give a little more clearness to matters in controversy.

Mr. Adams' proposition to admit New Mexico as a State is the only important matter. ${ }^{8}$

It would stifle the question about territory as this is all there is South of 36.30 The disunionists will of course refuse everything; but we want [to] deprive them of every ground of complaint and then let them stand clearly on persistent wrong. In the Caucus and among republicans I have opposed this because I preferred a general organization of the territories as incohate [sic] states which would in my judgment settle the matter and

The Committee of Thirty-three was appointed December 6, 1860, upon motion of Boteler of Virginia. Curtis was appointed the member of the Committee from Iowa. Majority reports of the committee were filed January 14, and the minority January 16. A consideration of the same was made a special order of the day for Monday, January 21. No formal ection of the House was had, however. Its purpose was to consider the proposals of compromise which might avert secession. Tension was so high, and tempers and mind so determined, that several members refused to serve on the Committee, stating they knew they could accept no compromise. See the Congressional Globe 36th Congress, 1st session, for appropriate dates.

"Thomas Corwin, Whig and Republican leader of Ohio served in both branches of the national legislature. In 1861 he was completing his last term as a Representative before taking duties under the new administration as minister to Mexico. state.

see Congressional Globe for references to New Mexico being admitted as a 
organize all necessary territories. But $\mathrm{Mr}$ Adams does not by his propositions violate our platform and if it tends to peace or tend to expose the obstancy of the revolutionists I am willing to go with those who must take some responsibility in their support of the chairman and $\mathrm{Mr}$ Adams.

We are in momentary anxiety to hear from Charleston where it is said troops and provisions have been sent to the relief of Major Anderson. ${ }^{9}$ As I said to you in a former letter, I do not care now how much S Carolina displays her quo animo it will rally the entire North to the resentment of insults and outrages already committed. My resolutions favoring the use of force were defeated in the Committee of 33 by a substitute introduced by $\mathrm{Mr}$ Dunn of Indiana-10 There is still a hope existing among some that we may avoid blood. I consider it impossible and therefor the sooner the appeal to arms be made the less extended will be the conflict and the sooner we may hope to see peace.

Nat Sturges is hear [sic] boarding with us and is enjoying himself generally $\mathrm{He}$ seems [as] clever and kind as ever and has some hope of securing some office under the incoming administration.

Last night we called on Miss Juliana May her mother and sister where we had a feast of music and very agreeable visit.

After that I went with the $\mathrm{Mr}$ Pennyman ${ }^{11}$ and made a call at the Speakers. ${ }^{12}$ Miss May gives a concert Thursday even'g for the benefit of some persons who sustain losses by a fire that occurred last week.

Legislation is proceedi'g while I write. We are very quiet while the gathering storm of the South continues to threaten the entire country. Perhaps you had best show this to Goodril. I will write him soon Give my love

\footnotetext{
MMajor Robert Anderson, West Point graduate, Southerner by birth and ante cedants, assigned to protect Charleston Harbor in 1860, was an unintentional hero of Fort Sumter. An earnest soldier he adhered to the Union cause in the war that followed. Cf. D. A. B., 1.

${ }^{10}$ William McKee Dunn, representative from Indiana 1859-1863, later rose to become Judge Advocate General in the U. S. Army.

i1William Pennyman, Governor of New Jersey 1837-1843, Whig member of Congress but one term, 1859-1861, was elected Speaker for that term, one in which much contention with the Chair was inevitable.

${ }^{12}$ William Pennington, see fn. 11.
} 
to our folks. I will answer Laiffe [?] and brother Hosmer very soon.

Affectionately yours

Sam. R. Curtis

Washington Jany 19. 1861.

\section{My dear wife}

I have not any thing very late from you, but before going to bed I feel desirous of writing you a few lines. I know the rumours of threatened attack on this city, and the continual advance of revolution, must create much anxiety; and my letters will therefore be especially interesting.

The great speech of Mr. Seward ${ }^{13}$ and the report of Mr Corwin Chairman of our Committee, and the general effort to show a desire to prevent a destruction of the Union; it is evident must create some consideration in Sections where people have not entirely got besides themselves. Mr Etheridge ${ }^{14}$ of Tennessee told me yesterday he had little more hope of reaction. Still the movements in several states are looked upon with much anxiety, and we every day feel that some trifling event will create new complications. So long as Virginia and Maryland are within the Union, according to their own resolves: this city is quite safe in my judgement. General Scott ${ }^{15}$ is collecting regular Marines and organising the Volunteers which he thinks "may secure the peace of the City." So he writes me in a private note responding to a letter sent through me from Col Whittlesey ${ }^{16}$ of Cleveland tendering forces \&c. If things appear to me the least dangerous I

\footnotetext{
${ }^{13}$ William H. Seward, Governor of New York, and leading member of the Republican party, later Secretary of State under Lincoln and Johnson, was a spokesman for the Compromise Republicans. His speech in the Senate referred to here, delivered January 12, 1861, was widely quoted in the press of the north. It caused some concern among Republicans because it was thought Seward had gone too far in hinting at willingness to compromise. A calm dispassionate speech. Seward rehearsed the history of comprise in the history of the nation. See Congressional Globe, 35th Congress, 1860-1861, pp. 341-344; Keokuk Gate City, Jan. 19, 1861.

${ }_{14}^{14}$ Emerson Etheridge, representative from Tennessee, 1853-1857, 1859-1861, followed that state into the Confederacy.

${ }^{15}$ Winfield Scott, southern born, entered the military forces in the War of 1812 , rose to rank of Brigadier General in 1814, and became a national hero by his fight at Lundy's Lane, 1814. In 1841 was appointed Commander in Chief, a position he held until age and physical debilities caused his resignation Nov, 1, 1861. A splendid tactician, an excellent diplomat, he was the Whig nominee for President in 1852 , being soundly whipped by Pierce.

${ }^{16} \mathrm{Col}$. Charles Whittlesey, graduate of the United States Military Academy in 1831, was a classmate of Curtis. A geologist of note and distinction, he served as a Col. in the Ohio Infantry until 1862. See Iowa Historical Records 3, 428-429.
} 
will send Sadie home with some of our friends who are visiting at this place. I received a letter from Henry ${ }^{17}$ dated at Cincinnati. He expects to be here about the $22 \mathrm{~d}$ or 24 th and wants to stay some week or ten days. By that time I can judge better of danger, but 1 do not think the taking of this city on the 4 th of March or before that time, is now at all probable.

Every day makes it less likely. It is not the work of a day to organize arm and equip forces as you know; and we do not believe there are many volunteers in Virginia that could be easily Collected for this point.

$\mathrm{Mr}$ Sturges and his son Shelton, are here occupying rooms in this house. Mr Sturges is quite nervous, but not near so much so as he was last year. Edward is also here yet. He and Sadie have gone to Resides to spend the evening.

I had a letter from Mr Stevens ${ }^{18}$ of Keokuk to day, dated at Springfield. He says I am still talked of there in Connection with a Cabinet appointment. Messers Harland ${ }^{19}$ and Vandever ${ }^{20}$ have both written letters very favorable to me. They much prefer my appointment to that of Warrens. ${ }^{21}$

It is very flattering to me, that I should be named in such honorable connection; especially that my Colleagues should so endorse me.

Mrs Andrews and Sadie are always together; and I am exceedingly glad of it, for the more I see of Mrs. Andrews the more I admire her.

She is very kind and confiding with Sadie, and I see she has her entire confidence.

The weather has been quite warm and spring like to

\footnotetext{
${ }^{17}$ Henry Z. Curtis, son of S. R. Curtis.

18.James Harlan, senior Senator from Iowa, 1853-1865, 1867-1873, served as Secretary of Interior under Johnson, 1865-1866.

${ }_{19}$ William Vandever, Representative from Iowa 1859-1861, and from California 1887-1891, was Col. of the 9th Iowa Vol. Infantry, 1861, raised to Brigadier General in 1862, was appointed Major General in 1865. He was a member of the Peace Convention of 1861 .

sofitz Henry Warren, a stormy figure in Iowa Whig and Republican polities, resident of Burlineton, was Assistant Post Master General under Presidents Taylor and Fillmore, 1849-1852. Warren was spoken of for Post Master General in 1861, which appears to have been the post for which Curtis was likewise recommended. Warren followed a stormy period on the Greely New York Tribune with an equally strife-filled period in the army, first as Col. 1st Iowa Vol. Cav., and as a Brigadier General in the state of Louisiana.

21Probably Manning W. Stevens, a farmer of Jackson Township, Lee County, who "acted with the Republican party since its organization."
} 
day, and Sadie has been out of school visiting the Smithsonian institutue with Mr. Sturges and Miss Delano who is at Willards with her father spending a few days.

The fluttering of the burner, shows that other gas lights are generally extinquished, and it must therefore be growing late. How does your money matters hold out? I must send you a draft if you need funds.

The 4th of March is approching, but none too fast to satisfy me and save the country. I look forward to it with anxiety, not merely because Lincoln is coming into power, but because I want to see you and my dear little daughter and all our dear friends in Keokuk.

Kiss the little darling for papa Tell her I do not think I can find any little sister pretty enough for a match for her. Besides I wonder whether she would love her big sister just as well. You know how much better she loves to play with little children than she does with us. I want her to play with me when the grass gets green and the flowers are bright and pretty like her.

Affectionately \& Ever yours

Saml. R. Curtis

H. R Washington Jany 19. 1861

My dear wife

Your letter of the 12th and 13th and 14th was duly received and has caused us great anxiety on account of the illness of our dear little daughter. We shall be trembling with fear for every hour that hangs over the uncertainty of her illness. I hope we will receive a letter today. If we do not we will hope she is not worse. You are so far away I will hereafter insist on your coming nearer to us during future sessions.

Things still look precarious. We have not power to do what ought to be done; and while revolution proceeds it is hard to say what would be best. This Capitol is the Key to our Nationality and it can only be with with Maryland. That it seems to me is a clear and incontroversable proposition. To hold Maryland we must try to do so pecibly [sic] for if forces be necessary to hold such a 
state against the will of her people will require a very strong force and the United efforts of every branch of our government. Unity everywhere and prudent Councils are necessary to hold this point and our impatient friends who wonder why we do not make more bluster should rather reproach the indiscretion of some who throw firebrands which are used by those who guard the citidel of a great good and glorious confederacy.

I send you a globe of today giving a 5 minute speech of mine on the power to hold border states. It is short and to the point, and the Gate ought to publish it. ${ }^{22}$

I have just made a speech of about 5 minutes on the subject Indian wars. It ought to be published also I will send it forward tomorrow. However this last should be published at Council Bluffs as it is more on frontier matters and excuses our frontier people for their unfortunate struggles in Indian difficulties. ${ }^{23}$

I had a long letter yesterday from Texas giving me assurances that the conspiricy [sic] for taking this capitol extends to Texas and is part of the plan of the Knights of the Golden Circle ${ }^{24}$ who No. one hundred and fifty thousand men Sworn to do any and everything to carry out their revolutionary purposes. The letters comes from an old friend and free Mason now in Texas. He says he does not want to see Sam Curtis Tom Corwin \& John Sherman assassinated. ${ }^{25}$

I think we are very safe so long as Maryland hold firm, but her secession cannot be accomplished in a day and cannot be accomplished without "the note of prepara-

${ }^{22}$ A short speech delivered January 19 , it was in reply to a resolution proposed by Jenkins of Virginia that none of the army approriations be used to recover forts or arsenals taken by states now seeeded, or from those which may secede. Curtis declared: "When the forts of the Government are taken by lawless mobs, I deem it my duty to vote for their recovery. . . . I would adopt every means of concilliation, exhaust all other means before $\mathrm{I}$ would resort to force; but, as a Representative of the United States, I could never consent to a proposition like that now offered. ...." Congressional Globe, op. eit., p. 461.

The remarks never appeared in the Gate City, largely because of the controversial Union meetings then in progress.

${ }_{23}$ Also a short speech, delivered the same day, January 19. Cong. Globe, 478. The speech was not printed in the Gate City.

${ }^{24}$ The Knights of the Golden Circle was organized about 1855 , had definite proSouthern direetions. During the Civil War it was an aetive Copperhead organization. cf. American Historical Review, XLVII, 23-50.

${ }^{25}$ Thomas Corwin and John Sherman, both of Curtis' former state of Ohio, were colleagues in the House of $\mathbf{R}$. 
tion" I am therefore very easy in my place in the performance of my duty.

You are very right in saying I ought to write to $\mathrm{Mr}$ Graham. ${ }^{26}$ Tell him he is not the less the first object of my influence.

Tell him (and tell no body else) I have set my eye on the office of 5th Auditor and I have the promise of the aid of Mr. Harlan ${ }^{2 \tau}$ for that particular thing. It is to audit the Post office accounts which I am told requires but little personal labor but the charge of clerks who do the duty.

We are all very well. Mr. Sturges Sadie and I have arranged to go over to George Town today after dinner to visit the Nichols. We are all very well and Affectionately yours

\section{My dear wife}

Saml. R. Curtis

We were glad to receive your letter to Sadie last night, and very glad to hear you and Caddie are so well. Some sore throat prevails here. Sadie has been complaining of it for a day or two, but she is about and attended a party with me last night at Mr. Greens, the old friend who lives in a splendid mansion near the Observatory. I had never been there, and we thought we must accept of his kind invitation after so many acts of courtesy received from him during the past 3 years. We were very kindly received and elegantly entertained.

Mr. Tate, his sister in law, and Dr. Tate brother in law are staying there, and I have seen no establishment superior to it in Washington. Mrs. Tate sent her regards to you, saying that she became somewhat acquainted with you two years ago. Henry did not go with us because he and Sadie had by some mistake, made another appointment at Judge Lawrance, where there was also a small and pleasant party. Ned Sturges, who is still with us went and spent the evening at Mr. Cox' quarters.

seprobably John A. Graham, former mayor of Keokuk, 1849-1852, a Virginian by birth.

27Senator James Harlan of Iowa. 
The public matters move forward in the same downward direction, but precipitation is not so rapid. Kentucky and other border states are disposed to look before they leap.

I have felt very little concern about the defenses of this city, because I have great confidence in General Scott who ought to provide against any pending danger.

We are supposed to be a deliberative body, and although we ought to assist in carrying out plans, we ought not to have the trouble and embarrassment of details or determination of the question of our own fortification. I say this to explain to you why we in the Congress do not make more fuss about the matter.

The force here is still very insignificant and the Chairman of our Military Committee ${ }^{28}$ has so intimated to the Secretary of War ${ }^{29}$ but the Department replies that the President is averse to calling out more force and against the introduction of a bill authorizing him to call out force. The object is to let matters run on, slipshod, till $\mathrm{Mr}$. Lincoln comes in, and then if we are all assassinated Buchanan would say "Shake not thy gory locks at me thou canst not say I did it." But my hope is that neither Virginia or Maryland will adopt precipitation and without the secession of these States, there is little or no danger of any attack on this city.

Besides such a movement could not be made in this country without more of a note of preparation.

Henry is enjoying himself, and I hope he will stay a week or two before going west.

He has a bed in my room, so that Mrs. Joy will only charge something like day boarding. In this way it will not cost much more that it would in Omaha.

Dear little Caddie, I am very glad you are well and growing larger every day. I hope you will read me a pretty story when I get home. I tell you daughter these

\footnotetext{
${ }^{28}$ Benjamin Stanton, representative from Ohio 1851-1853, 1855-1861.

29 Joseph Holt, a Kentucky Democrat. Appointed Commissioner of Patents 1857 to suceeed Charles Mason of Keokuk, Iowa, Holt was designated Postmaster General in 1859. A sympathiser of Southern sentiment at this time, he inclined to the Union cause when appointed Seeretary of War January 1, 1861, to succeed John B. Floyd, resigned. He actively sought to keep Kentucky in the Union, and later, as Judge Advocate General under Lincoln and Johnson supported the Radicals in Congress. See D. A. B. 9, 181-183.
} 
little sisters here are not much better than your dollieIndeed they are not nice enough to make sisters to you and I am not willing to buy them.

You may think Cousin Helin [?] got a very pretty little Cousin and therefore I might get such a one for you; but I tell you there are no more of that sort. Mrs. Morris' baby has black hair, and I don't like black headed babies-do you? Besides she won't sell hers at any price. Don't you think she is green? I think it cries and bites her too! Well, if I cannot get a little sister for you, perhaps I can get you a little book or a little pairsol or something else

You tell me something that will please you just as well as a live sister baby.

Ever Affectionately yours

Saml. R. Curtis

\section{My dear wife}

Washington Feby 3. 1861

This is Sunday and my birthday ${ }^{30}$ and it would be wrong to pass it over without writing to you. The past week has been passed in the usual way, except that I have attended two or three evening parties. One at Speaker Penningtons a very nice one. Sadie had the headache and could not go. One at Mr Forneys a Gentleman's party where we sang hail Columbia and the Star Spangled banner with great glee. One at Willards to meet a New York delegation who came to bring the petition of 40,000 favorable to compromise.

Sadie was out with Henry at hops on several occasions also where they all enjoyed themselves very much. We were sorry to part with Henry on Friday I tried to prevail on him to stay longer but he thought it would not do for him to delay any longer.

Revolution has been moving on regularly and tomorrow will determine the fate of Virginia and probably the fate of other border States. If they all determine on Secession it is hard to see what will be the extent of the future Ohio.

${ }^{50}$ Born February 3, 1805, near Champlain, N. Y., while family was en route to 
disaters to our whole country. It will unsettle the National Government by establishing facilities for disunion which will render all new unions entirely unsettled and uncertain. $^{31}$

Yet that is not the immediate consequence and therefore it will not be so generally appreciated The immediate effect will be a strife in regard to the ownership of this the Capitol of the United States. More force will be needed to hold Washington and immediate efforts will be taken to secure it. Hitherto the President has resisted every effort to prepare or procure force for the occasion ${ }^{32}$ but I think in the event of secession in Va the necessity will be so apparent no one will object to it.

The Union men in Virginia are hopeful and may carry the election. If they do there will be a great check on revolution as Virginia has deservedly a great influence in the South. ${ }^{33}$

$\mathrm{Mr}$ Sturges is here writing at my table. He is very well and entirely himself. Yet he is always in my room and he and Ed together occupy too much of my time and that of Sadie's too. Kate and one of her brothers are expected this week and that will not reduce the interruptions. Of course I go on with my writing but I have no time to think or study while my room is so occupied.

Our last letter from you was written to Sadie after you had dined at Laiffes I believe You were all very well then and busying sewing. I would not bother much about pillow cases till we know how long we are going to remain at home Certainly do not add to our furnature [sic] which we will have to rent or stow away.

I wish you and Caddie were here. It is rather pleasant although I have not been out to enjoy it. Am talking of going out with Mr. Sturges who is enammoured with all

\footnotetext{
s1 In January Virginia authorized the election on February 4, of members to attend a state convention to determine that state's position in the developing threat of federal schism. The election was a decided triumph for the conservative-compromise forces. $C f$. Rhodes, 3, 309 .

${ }^{2}$ Buchanan wavered between a desire to avoid Civil War while president, and a sincere desire to refrain from agression on the part of the North. His poliey changed markedly after Janvary, 1861, with changes in his cabinet. Scott, Commander in Chief of the Army, was not in good graces with Buchanan, and only moved his headquarters from New York to Washington in December, 1860.

${ }^{3}$ See $\mathrm{fn}$. 31 . The result in Virginia had a great influence on Tennessee and Maryland particularly.
} 
the ladies especially one friend in Georgetown-But I think he sees too many wrinkles [?] on some of their faces to satisfy his fancy. He has offered 15 thousand dollars for $\mathrm{Mr}$ Nicholls' property but that is not enough for it and therefore he is not likely to get it.

Mr. and Miss Delano ${ }^{34}$ are here at this house and Miss Delano is a fine companion for Sadie. She also occupies too much of Sadies time. But she is a very smart and agreeable girl. Delano is anxious to be one of the Cabinet. What his chances are I cannot say. It seems agreed that Chase $^{35}$ cannot be admitted as one and somebody ought to be taken from Ohio Perhaps he may be.

The proceedings of the Union meeting in Keokuk were not such as to unite the North. I am sorry to see such divisions when we ought to be United. ${ }^{36}$

Divisions must be disposed of in some way, or instead of having the South to fight neighbors will be fighting each other. The revolutionists are uniting the South most effectually

What about money. Are you in need of funds? I have my deposit so it draws interest in New York and only want to draw when you need it. Have you killed the old cow? Has the farms brought you in any provisions? How are the things in the garden are they all safe. I will send you some seeds soon. I suppose the river is closed and therefore you have no boats running. Kiss Caddie

\section{Affectionately yours \\ Saml. R. Curtis}

\footnotetext{
${ }^{34}$ Columbus Delano, of Ohio, an ardent Republican leader of that state, was among those who seconded the nomination of Lincoln in Chicago in 1860 . He served in Congress, 1845-1847, 1865-1869, and as Secretary of Interior under Grant, 1871-1875.

s5almon P. Chase, ardent Whig, Free Soiler, and "Black" Republican served Ohio in the U. S. Senate 1849-1855, 1861. His selection for a cabinet position was strongly opposed by Seward followers were were more favorable to compromise than was Chase. Chase was a strong favorite son contender for the nomination in 1860 at Chicago.

arkeokuk, south-east tip of Iowa, was a strongly Demoeratic stronghold. The impending Civil War sorely tried the faiths and loyalties of that party. A Union meeting called by the principle Democrats was held January 19 , and adjourned to January 23, at which time vigorous arguments ensued in a disharmonious fashion over the rights of secession, and the virtues of the Crittenden compromises. Democrats were willing to let the seceding states go rather than wage war, the Republicans present were not.

A second meeting of the Democratic adherents in Keokuk was held January 26, at which time the Crittenden compromises were generally approved. Such a report showed little unity or harmony, these divided counsels boded ill for a vigorous policy. See Keokuk Gate City, January 19, 23, 25, 27, 28, 1861.
} 
My dear wife

Washington Feby 8. 1861

Your letter was duly received last night, and I send you a $30 \$$ draft which our [?] Mr Stanton has just received.

I had received a letter from Sam about the same date as that of yours. I am glad to see he is re elected warden of the church and have so written him. Such an office is not only very honorable but it will act as a restraint on him.

You say my letters do not give details That must be so I am much pressed with care private and public, and I am kept so busy I have no time to look at any one subject any considerable length of time. Sadie is busy with her school and with company and I feel too poor to hire help; so I work incessently. The Convention is becoming a very important matter. Most of the States have now appointed delegates except the Seceding states and I want to attend that body as much as I can-Since the election in Va and the assembling of that Convention things look a little more hopeful but they are hard enough yet ${ }^{37}$

Do not fail to write very often I wish you was here to assist in sending off seeds and documents. Mr Stanton helps me considerable but he expects nothing and I shall not pay very much I can assure you. I fear we will be sold out yet. Still let us hope on they cannot hang us for being poor. I am possessed of good health also and can perform a vast amount of work. I am glad also to see our boys have good health. If Henry does not go by Keokuk you will no doubt be much disappointed. I kept him longer than $\mathrm{Pa}$ seemed to think he ought to stay; and yet he only remained 11 days

I want you to write them often. Kiss my dear little Caddie. Kate Sturgis is spending a few days with Sadie $\mathrm{Mr}$ Sturgis however is down spirited and insists on going home very soon

\footnotetext{
"The "Peace Convention" or "Border Slave States Convention," convened in Washington February 4, at the suggestion of the Virginia legislature, with representatives chosen either by state legislatures or state conventions. Only 21 out of 33 states were represented. Iowa was represented by Harlan and Vandever. The Peace Convention, doomed to failure before it met, came to no acceptable conclusions, for the Crittenden Compromises were not acceptable to many of the North, and less was not acceptable to the South.

The same day commissioners from the seven seceded states convened at Montgomery, Alabama, to draw a provisional government of the Confederacy.
} 
Sadie is very well. It is awful cold just now I fear you will find it much more so.

Affectionately yours

Saml. R. Curtis

My dear wife

Washington Feby 10th 1861

I received a dispatch and then a letter from Henry $H$ Curtis $^{38} \mathrm{~S}$. Louis urging me to make out a mortgage immediately to secure his debt $\mathrm{He}$ says the court is in cession and judgements will be increased against me so as to endanger his claims.

I do not understand that court is siting I wrote brother Hosmer on this subject some time ago. I supposed there would be no more courts till some time after the adjournment giving me a little time for reflection and arrangement. I wish you would ask brother Hosmer and write me immediately. I wrote Henry I did not wish to give any more mortgages unless I could postpone difficulties and expressed a preference for an assignment. If others are trying to get ahead I must prevent injustice among friends.

Mr Sturges is here quiet and rather disconsolate. Sadie Kate George and Edward have been enjoying the last two days sight seeing. They are gone over to see the Coxes this evening. It has moderated as Suddenly as it became cold last week. I never saw such sudden changes. I see by the papers there was a great snow storm north. I suppose you had your share of it at Keokuk and I fancied you and Caddie would have a renewal of bad colds. I could hardly keep warm by a good coal fire here in Washington and you must have felt it much worse there at home.

The first instalment of news from Tennessee comes in today favorable to the Union. If Tennessee comes up right I shall consider the border States quite $\mathrm{safe}^{39}$

\footnotetext{
${ }^{38}$ A relative whose address was also given later as Quincy, Illinois.

${ }^{2} \mathrm{~A}$ call was issued for a state convention in Tennessee on January 7, 1861, to consider position of the state in the impending crisis. The elections, held February 9, gave the Union friends a clear 67,000 majority, the people voting down the holding of a convention. After Sumter, however, the tide of secession rose rapidly, and the state cast its lot with the Confederacy May 1, 1861. Cf. American Annual Cyclopedia, Appleton \& Co., 1861, pp. 677-679.
} 
The Southern Convention-however-have elected a strong President and Vice President-Davis and Stevens. ${ }^{40}$ They however may be better able to secure a compromise as they are both very reasonable men; but if they will not have adjustment and union; then these men are formidable as leaders of a Southern Confederacy

It looks in their hands like a defacto Government likely to be respected by foreign nations and therefore likely to be permanent fixture. It looks as though my apprehensions are to be consumated. The republic will be divided before $\mathrm{Mr}$ Lincoln takes his seat and $\mathrm{Mr}$ Buchanan will pass over only a broken septer [sic] and divided sovereingty The democracy will glory in the shame of having transmitted to their successor despoiled treasury a divided country and a civil war. Let us hope that enough may remain to restore the tottering edefice and secure a renewal of the happy days of our great republic.

My mail last night was so overwhelming, I have laid it aside and attended church today. I should have taken a walk it was so pleasant but somehow I neglected it until it was too late.

The city is filling up with strangers. The Peace Conference has increased till it makes a large assembly. My business in the House prevents me from doing much at the Convention. Mr. Harlan has the post of Committee man there and I leave him to try his hand as Grimes, Vandever, ${ }^{41}$ and I have done on former occasions. $\mathrm{He}$ thinks they will agree to leave the matters to a convention of the people. I suppose this may do: but it will continue and perhaps embitter the slavery discussion throughout

40 Jefferson Davis, graduate of West Point in 1828, veteran of two wars, representative in Congress from Mississippi, Senator, and Secretary of War under Franklin Pierce, was an ardent States Rights Southerner who probably yearned for the command of the Confederate armies more than for the presidency. He resigned from the U. S. Senate Jan. 21, 1861. Inaugurated President of the Confederate States of America February 18 and 22, 1861. He was a contemporary in the Senate with Curtis.

Alexander $\mathrm{H}$. Stephens, a short, crippled representative from Georgia, was, prior to 1861, a compromising Democrat, serving in Congress from 1843 to 1859 . Elected Vice President of the Confederacy in February, 1861, after the war he served in Congress from 1873 to 1882 . He likewise was a contemporary in the House of Curtis from 1857 to 1859.

"1James W. Grimes, junior senator from Iowa, one of the three principle leaders of the Republican party in the state, served as U. S. Senator from 1859 to 1870. $\mathrm{He}$ was one of the Committee of 13 appointed in the Senate December 18, 1860.

Vandever see fn. 19. 
the country. It may defer disastrous civil war and possibly give time for sensible reflections.

My correspondence is mostly about office Every candidate gets his friends to write as much and as often as possible.

The apprehensions in regard to the taking this capitol grow less as military companies arrive daily and the determination of the border States look more towards perpetuating the union. We have now near a thousand regulars here, and the danger of attack is therefore insignificant. If reaction takes place in favor of secession we will make further guards against accident.

Continue to write often and fully. I am glad to see the time now begins to shorten. Only 3 weeks. A long time in revolution: and much may traspire during this period. Still the dangers that threatened Lincolns advent seem to have received a quietus by the Virginia election. And I regard his inaugeration as an accomplished fact.

Much love to all and many kisses to Caddie

Affectionately yours

Saml. R. Curtis

My dear wife

Washington Feby 19. 1861

While the Navy bill is being discussed I will say a few words to you. I was agreeably surprised last night at the arrival of Uncle Johnny who steped into my room as fresh and fair as a young girl of ten years. He is going the rounds today I suppose I left him with $\mathrm{Mr}$ Harlan this morning

The town is filling up with strangers, generally seeking office. The news from St. Louis giving the news of the election there going strong for the Union creates quite a censation [sic]. I hope the news may be corroberated everywhere. In the mean time the peace Conference is trying to get something through that body that will hold Virginia; for she seems to be doubtful yet. A great noise was made here this morning because we tried to get a bill through authorising the President to call out the Militia in case of insurrection. 
I see we will have trouble in spite of all peace measures and Union sentiments. The Cotton Confederacy seems pretty well organized and they are making preparations for war on rather a large scale. Every step of the kind makes them more and more irreconsilable [sic]. The question of the border states is different. Secession with them is a little more of a practical danger and therefore the hesitation

If however the border states are going to prevent us from executing the laws they were better out than in.

I see by your last letter that we said but little about Henrys trip homeward He did not himself determine as to whether he would go to Keokuk and we could not therefor advise you. No doubt he will give you satisfactory reasons for not availing himself of such an occasion.

We were much delighted with Caddies letter to Sadie She talks about little things we like to hear. As to my letters how can you expect me to go into little matters when I am so overwhelmed with matters which seem to involve the whole country.

I am glad to see the time still shortens, and the day of inaugeration is close at hand. We will then have to leave matters with the new executive who I am sorry to see will come into power surrounded by revolution and very little power to repel foes.

Kiss little Caddie for $\mathrm{Pa}$ and give my love to all our friends.

Affectionately yours

Saml. R. Curtis

Washington Feby 241861

My dear wife

Although I have about finished a large table full of letters, I must not close writing till I give you a few broken sentences. Before this reaches you, you will hear of $\mathrm{Mr}$. Lincolns arrival at this place, and that he came through by a night train without complying with his programme so unfortunately prolonged and so foolishly 


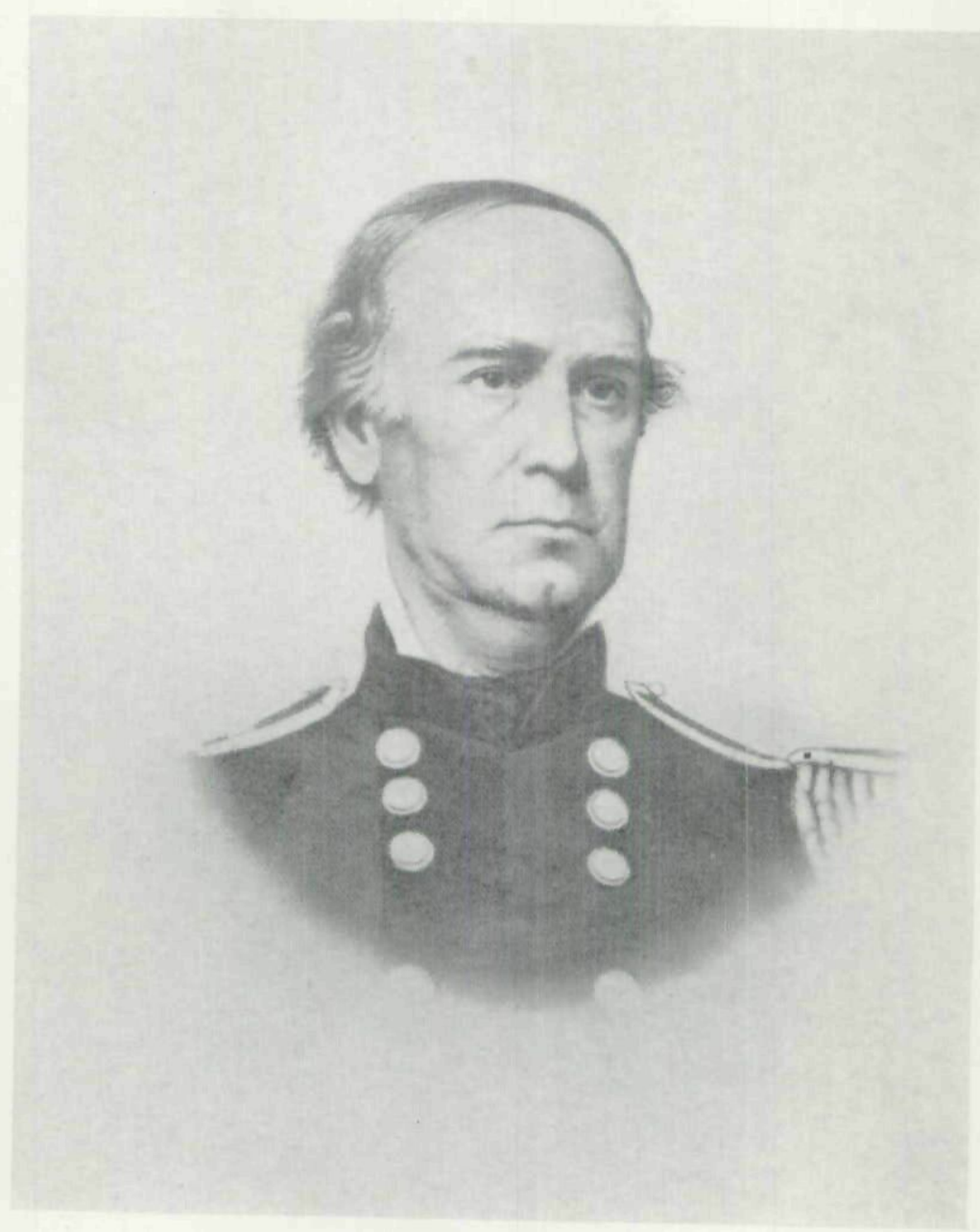

SAMUEL RYAN CURTIS 1803-1866

Soldier, Engineer and Congressman 
performed. ${ }^{42}$ I regret the whole matter. First that he made the array of a programme Second that he made light of grave questions, and finally that he did not carry out the programme at all hasards. But I make no open fuss about matters comparatively trifling and hope his inaugeration and policy may justify all our hopes. But there should not have been the least display of alarm. Courage and prudence are the utmost importance at this crisis of our affairs, and although his coming was no doubt a prudential [?] arrangement made by others, yet it will be reflected on him and will be charged to timidity.

I have not called as yet to see him. I hear he looks care worn and weary, and I do not wish to annoy him. Certainly his position is not to be envied. The democracy may rejoice in leaving him a barren scepter. The great republic that has been the pride and glory of the world is I fear a broken vase which will defy the potters skill to restore.

But I will not despair. Some time may be given to things which will restore peace and harmony.

The breach has grown too wide and too deep to be remedied by threats or denunciations. Settlement or civil war is now the dilemma. I see you and other friends so remote still mistake the matter as a new Slavery question, and overlook the greater evil which is here more appararent because it seems to sap the foundation of Civil Society and threaten the peace of every fireside in the country. Liberty must subscribe to law or anarchy follows and despotism after. Many are now beginning to long for a stronger government. If the republicans break up and democracy resume the ascendance, the danger is they will supply anarchy with a powerful military government. Even if republicans hold power they must materially increase their military strength. A firm but very prudent policy may conquer revolution: but every step we take is so persistently misconstrued and used to aid the Southern

${ }^{42}$ Abraham Lincoln's progress towards Washington, an 11 day trip, took him through the major cities of the north. On Feb. 22, at Philadelphia, he was persuaded to forgo the stop at Baltimore upon representations of a plot to assassinate him there. In consequence he boarded a special train and slipped into Washington by night, arriving at $6 \mathrm{~A}$. M. February 23. The reaction of Curtis was a feeling possessed by many, although definitely difficulties would have been encountered in Baltimore. Cf. Sandburg, Abraham Lincoln, the War Years, I. 
excitement; it is still hard to tell what a day or an hour may bring forth. Virginia hangs on a pivot. Her Convention might turn the scale either way. She has checked the progress of revolution but holds the shafts in her hand ready to let the $[\mathrm{m}]$ loose if the peace Convention does not relieve the terror of her people. Maryland stands ready to follow Virginia in whatever may be her determination. In the mean time the masses are thrown out of employment. They are restive and revengeful: and unfortunately in all this region their misfortunes are charged on republican rule; although republicans are not yet in power. The inaugeration is likely to be a gloomy pageant. There will be apprehensions although I think there will be no danger. But the anxiety will be apparent, and the display will therefore appear gloomy.

During the past week I have been going to and fro between Congress and the Peace Convention, at the same time laboring to keep up my everlasting correspondence. The city is becoming crowded with strangers among them many from Iowa including $\mathrm{Mr}$ Graham Hawkins Taylor and Mr. Kasson all of whom you know. ${ }^{43}$ Sadie is very well and is expecting $\mathrm{Mr}$ Bridgeman ${ }^{44}$ with Clara and his sister tomorrow to spend a few days. We have got rooms adjoining for them and therefore they will be very near us.

I received letters from Sam and Henry both today. Sam is at Denver or was when he wrote on the 2nd and Henry is at home from whence no doubt he will write you very fully. Sam wants the Post Office at Denver and I am going to try hard to get it for him. The delegate ${ }^{45}$ goes for him and says he has a right to it being quite as

\footnotetext{
${ }^{43}$ Hawkins Taylor, resident in Iowa since 1836, prominent in county politics, was an early Republican supporter of Abraham Lincoln. He succeeded Curtis as Mayor of Keokuk in 1857. His appointment as Special Mail Agent was made shortly after March, 1861.

John A. Kasson, able lawyer, suave diplomat, efficient administrator, with Taylor was a member of the Iowa delegation at Chicago in 1860 . His reward was the appointment as First Assistant Post Master General in 1861. Aside from three periods as representative in Congress, Kasson gave distinguished service to the nation as ambassador abroad and in the administrative negotiation of numerous special treaties and at numerous international conferences in the post Civil War years.

${ }^{44}$ Arthur Bridgeman, an Iowa settler since 1838, merchant, Register of the U. S. Land Office at Fairfield, and railroad promoter, by common courtesy called "General." A native of Massachusetts, he was since 1849 a resident of Keokuk.

${ }^{45}$ Hiram P. Bennett. The territory was not granted a delegate officially until February 28, 1861.
} 
prominent and efficient as any other public man connected with the public service out there.

Goodril is excited about the Post office or some other office and you must try to cool him down. It would not do to get him the Post Office in the face of so many prominent political aspirants and I am surprised that he should have dreamed of it. James too wants office. He is better known among political circles but I am so overshadowed and overloaded with applications I can form no idea of what I may be able to do. I will do the best I can for both of them of course consistant with justice and reason.

You better not show them this letter, but quietly cool their arder as much as you can: for they must be disappointed in the scramble that surrounds the avenues of power.

It is about 8 oclock P M and I have not been out doors today. Kiss little Caddie for me. This is the last week of this Congress during which $\mathrm{I}$ have a vast amount to do. After the adjournment I hope to have a little more time to consider matters about which my constituents are anxiously looking and I shall therefore stay long enough to fix up my papers and see the lay of the field for office

Affectionately yours

Saml. R. Curtis

My dear wife

Washington Feby 28. 1861.

I did suppose I would not have another moment to write to you; but while there is a discussion going on about the Indian bill, I will drop a line merely for the purpose of sending you the photograph of Edward Sturges and say we are all very well. The day is delightful. Sadie was invited to go with friends to Mt Vernon but she has been so much disturbed in her course of studies I declined my leave. Yet when I came to the capitol grounds and saw the yellow crocus peeping brightly and enjoying the bright beams of a summer sun and the soft air of a summer day I wished I could go and Sadie too and enjoy the day on 
the bright waters of the Potomac and in the groves of Mt. Vernon

But here I must stay. I called to see $\mathrm{Mr}$ Lincoln this morning with General Wool ${ }^{46}[$ ?] but there is always such a crowd about him that I feel no satisfaction in the call. $\mathrm{He}$ is overwhelmed with visitors and oppressed with care. We have those around us republicans who seem to care nothing for consequences as though consequences are outside of moral obligations.

Our Union friends of the South are cheered and will fight more earnestly for our country because they Consider it a good omen. The South must fight the South if any body has to fight and I think yet there is much danger of such consequences.

This is Thursday

Affectionately yours

Saml. R. Curtis

Washington Mar 41861

My dear wife

The inaugeration has gone off very quietly. The attendance was very great and the day very delightful. Congress finally passed through both houses the measures proposing amendment of the Constitution so as to prevent one state medling with other folkses business and some other matters suggested by the Committee of $33 .{ }^{47}$ The Senate set all night. Grimes \& Harlan both voted for the compromise measure. $\mathrm{Mr}$ Lincolns speech was concilliatory but firm. It approves of the concilliatory measures but ably argues the duty and necessity of executing the laws.

Unfortunately we could not carry any measure to enforce obedience when the difficulties amount to great magnitude So the President cannot do much without ex-

${ }^{40} \mathrm{John}$ Ellis Wool, began his military career in 1812, rose in ranks until a Brigadier General in 1841. He served with Taylor in the Mexiean War. Curtis was a member of Gen. Wool's staff during that war. Following 1856 Wool was Commender of the Department of the East. Probably connection with some of the military bills before the House and the defense of Washington brought the two acquaintances together before Lincoln.

"7Passed February 27, proposed: "No amendment shall be made to the Constitution which will authorize or give to Congress the power to abolish or interfere, within any State, with the domestic institutions thereof, including that of persons held to labor or service by the laws of said State." 
ceeding or being charged with exceeding his functions. The Union men of the South and the people of the city seem pleased with the spirit and tone of the message as well as the final action of Congress.

These may give a further check to revolution and disappointment the malevlent [sic] hopes which some fanatics entertain that a general insurrection and bloody civil war would be immediately inaugerated. Yet this will not satisfy the revolutionists. They will try hard to keep up the storm. Wigfall ${ }^{48}$ [?] told me he liked the message it was " 'war to the knife and the knife to the hilt' and if we do not remove our troops they will attack them next week." Of course he is determined to make everything a menace however kindly the tone and conclusive the logic. They will now have no earthly excuse. If they are determined to invoke war they will find it difficult to prove to the world we are the aggressors, and they must proceed with a consciousness of wrong surmounted with a painful conviction that we are right.

If revolution can prosper under such auspices surely the days of the downfall of civilisation like that which devasted Rome has returned to dessolate the world.

Sadie has too much headach to go to the great ball tonight so I am working in my room surrounded by Uncle Johny, Mr. Scholte ${ }^{49}$ and others. It is late. I will enclose Sams last and bid you good night.

Affectionately and ever yours Saml. R. Curtis

\section{My dear wife}

Washington March 17. 1861

I have not had an hour of peace and quiet since the adjournment. I have new friends coming daily, and new matters to be attended to-directed by every mail.

I did hope to be at home to-day: but could not leave till I had secured some places beyond a peradventure.

\footnotetext{
46Luis Tresvant Wigfall, U. S. Senator from Texas 1859-1861. A native of South Carolina he was an ardent Sonthern rights man, was present at the firing on Fort Sumter, later served in the Confederate army.

"Hendrick Peter Scholte, "Domine Scholte," leader of the Hollanders who settled at Pella, Iowa, in 1847. A man of brilliant attainments, early a Democrat, joined the Republiean party in 1856 .
} 
I have now secured a place for Mr. Stanton, who has done a great deal of document work for me this winter, at 1200 a year $\mathrm{He}$ is also editor of the Washington paper. For Uncle Johnny I have secured after much labor the office of chief clerk in the Registers office 2000 a year which pleases him entirely.

I have also got Grinnell ${ }^{50}$ appointed Secret Mail agent, and the promise and order for a hoste of P. offices including Keokuk for Howell.

Of course I will disappoint thousands of active old influential poltical friends and to have given Goodril or James appointments would have exasperated such men as Stevens, Fulton, Genl Bridgemen and others who want the same offices. I will at a proper time try to get places for both but I must not and you must not encourage it; for I am determined to first try to secure places for our own boys who have really deserved places because of their public efforts in two territories. But they will be charged to me as family affairs, and I must not do too much of this. Sams appointment is safe. Henrys is not yet certain. Mr Stevens was a candidate for Marshall but we gave that to Hoxie ${ }^{51}$ who was a great worker as Chairman of the State Committee.

Conn, Burns, Shart [?], and fifty more, will complain because they could not be something. I have got along with appointments so as to hope to get home this week At any rate. I hope no new difficulties will arise. Uncle Johnny wants to stay till he is fully inaugerated. Of course I must see that all is done which is deemed necessary to aid such a working friend.

He has aided in arranging papers, writing letters \&c \&c, every since he came.

This is Sunday. I ought to go over and bid the Georgetown people goodby before I leave Jinny was over and left a note for her friend Hollingsworth to get a clerkship Everybody wants aid. Wallace Curtis is here, and I would like to aid him. He has been a working editor in

\footnotetext{
שoJosiah Bushnell Grinnell, founder of Grinnell College, Grinnell, Iowa, was a member of the Iowa delegation at Chicago in 1860 . Following two years as Special Mail Agent he served in Congress from 1863 to 1867.

"i1. M. "Hub" Hoxie.
} 
Fulton and ought to be aided by Illinois Politicians. Ned is here yet. He has come down to demand a $\$ 2000$ Consulate and I think stands some chance. But he can make no great political showing as he has not been much of a politician.

You see how my minds runs with my troubles. Hawkins Taylor and Mr Turner are also earnest and active workers in the general scramble. Hawkins will be Special Mail agent on Keokuk and St. Louis mail line. Sadie is very well and I am as ever

Affectionately yours

Saml. R. Curtis

With the first shots fired on Fort Sumter, April 12, and the capitulation of that Charleston, South Carolina, post two days later, the long dreaded "irrepressible conflict" burst into flames. No longer doubting, hesitant, and divided, the North leaped to its feat in one spontaneous demonstration of will and a determination to Save the Union!

A vital object of the federal forces in those first days was to secure an imperiled and all but defenceless Washington. The first state able and prepared to furnish troops for this purpose was Massachusetts, under Governor John A. Andrews. The 6th Massachusetts entrained for Washington April 17, arriving in Baltimore two days later. In that hostile southern sympathising town, avoided by Lincoln because of its uncertain temper two months before, the Massachusetts troops were met and attacked by a rioting mob of anti-unionists while marching through the streets to transfer from the Philadelphia to the Washington trains. In the exchange of shots several on both sides were killed. The threat to Washington rose higher and higher, cut off from the North.

Such a state of tension ensued that Union Governor Hicks pleaded with the federal government to send no more troops through his unruly city. The remainder of the Massachusetts troops, the 8th, were ordered not to disembark when they arrived before that town by boat 
shortly thereafter. Railroad tracks and bridges were torn up to prevent the arrival or departure of additional troops. Washington was completely cut off.

In the meanwhile other troops were already enroute to Washington. The 7th New York entrained from New York City April 19, the day of the Baltimore riots. At Philadelphia they were joined by Samuel R. Curtis, hurrying on his way to Washington from Keokuk at the news of the attack on Sumter. With his military experience and his congressional standing, his aid was eagerly welcomed by Col. Lefferts of the 7 th New York. From Philadelphia the regiment traveled by train to Perryville, thence by the Steamship Boston to Annapolis. At this point Curtis picks up the story again in his family correspondence.

\section{Off Annapolis Steamer}

Boston Apl 221861

My dear wife

I wrote you yesterday ${ }^{52}$ just as we were entering the mouth of the Chespeak and just as I was called to a Council of War.

The Col it seems had no definite directions as to his route and called us to consult as to whether he had best to up the Potomac direct to Washington or up the Chespeak to this place. From the dispatches which he had it seemed the idea of the department that our route should be this way \& the map also showed this would be the best as the bay is so wide we can avoid batteries on the shore. We passed up therefore without any molestation and find Genl Butler ${ }^{53}$ of Massachusetts with 700 Volunteers who are laying off in another steamer

I went with the Col and Capt Hamilton ${ }^{54}$ (this latter was formerly an officer of the army and aid for many

\footnotetext{
52Letter not found.

${ }^{53} \mathrm{~A}$ stormy figure in national polities for the next twenty years, a pre-war Democrat, he vigorously supported the war measures of the Republican party, served as a Brizadier and Major General in the federal army, was elected to Congress, 1867-1875, 1877-1879, supported the Radicals in their attacks on Johnson.

64 Sehuyler Hamilton, graduate of West Point, 1837, captain in the Mexican War. he resigned from the army in 1855, enlisted as a private in the 7 th New York State Militia April 19. Later Brigadier General of volunteers in 1862, resigned in 1863.
} 
years to Genl Scott now a private in this Regiment.) to see Genl Butler $\mathrm{He}$ is directed to establish a depot at this place and [he arrived-in pencil] here just in time to save the great and glorious Ship Constitution which was about to be seised by a party on their way from Baltimore to seise her. There was also great danger of the Navy School which is here. We are going to land and make temperary fortifications and try to open the way to Washington.

It seems the railroad from this point to Washington is torn up but it is only about 35 miles and we can walk that if we cannot go by rail.

Of course my military experience and services are in demand and I am busy assisting Col Marshall Lefferts and Genl B F Butler being I suppose you may say on the staff of each.

Just at present I am franking letters to the wives and sweethearts of the men who seem to think, I am assigned to this special duty As their letters all report the proceedings of the expedition I consider all the letters on public service reporting for the public good From the number they present I should think they are all newspaper reporters, and from the address of their letters they all seem to be of the upper ten in N York for they direct to 22nd 21st and other of the fine localities of that city. ${ }^{55}$

I have not had my boots off except at Philadelphia since I left home and have since I came on this boat eaten only hard biscuit and one small bit of stake [sic] which I obstained for 25 cents yesterday. But I am in excellent health and spirits and only feel fearful that you and Sadie will not get earlier news from me and may think me among the killed in Baltimore or some other place

\section{Affectionately \& everyone}

Saml. R. Curtis

\section{My dear wife}

Annapolis April 23d 1861

We the 7th New York Regiment and a Regiment from

${ }^{65}$ The 7 th New York, due to its flashy gray and blue trimmed uniforms and its aristocratic membership was quickly called "dandies" on their arrival in Wash-
ington. 
Massachusetts under the command of Genl Butler have landed and are encamped in the beautiful grounds of the Navy yard with the Corps of Midshipmen. I say we because I have been with them laboring and toiling till I am weary and so warm I can hardly write. I have been too busy to do much writing, but no opportunity seems to have offered since I embarked on the Boston ${ }^{56}$ for this place and Washington I do not now much expect to get a letter [?] through, but some opertunity [sic] will no doubt offer, and I will give it a trial. We had a pleasant Steamboat trip to this place Saving the personal inconveniences that one suffers in a boat so crowded you could not get room to lay down and bread of the hardest kind being the only fare. Last night I had the good fortune to get a nights lodging at the eligant [sic] house of Capt. Blake $^{57}$ who is Comt of the Navy Yard. Genl Bridgeman knows therefore that for one night since I left home I have had comfortable quarters.

I hope we will have sufficient transportation to move on tomorrow. We are within about 35 miles of Washington in a straight line, but the means of travel has been cut off and the people through the Country are hostile and arming.

Of course this is just as I expected and if it takes time to fight through I shall also try to patiently and steadily work my way with the troops who are on their way and ready to do their duty. I am in the staff duties of Genl Butler Col Lefferts and the United States just as I can be most useful.

I am in excellent health and about able for all the accidents of the service. I am directing the formation of this depot which I think will become the greatest depot in the country.

My advice included [?] the particular location and arrangement of landing and I was with the first to enter the city.

ธoEmbarked at Perryville.

${ }^{\circ}$ George S. Blake, midshipman 1818, commander, 1847, captain, 1855 , and commodore, 1862 . Blake was actually superintendent of the Naval Academy at Annapolis, a post he assumed in 1858 . 
Affectionately \& Ever yours Saml R Curtis

I close suddenly because an express is ready to go

My dear wife

Washington Apl 27. 1861

I arrived here with the N York regiment on Wednesday after a steady foot march of a day and a night assisting to haul canon build railroad and chasing the garilla [sic] forces that we found in our way.

I have visited all the heads of departments and reported everything. I have no news from our Governor ${ }^{58}$ but I have told the different officers Iowa is no doubt ready with her regiment and anxious to furnish several more.

Genl Scott told me he wished I had a Commission as General of Militia. He could at once give me power to give orders which I cannot do without a Commission in the Militia service. Ask Genl Reid how I can get such an authority to act A staff appointment will not do. I need a commission of $\mathrm{Col}$ or Genl the higher the better and by being ordered by the Govr my status would enable me to receive General orders from the department which the General knows I could develop in detail.

I am very well and very busy. Sadie will write more fully than I can.

You may know where the Governor is and can hurry up such instructions from him with some sort of commission that will enable me to procure arms and munitions for the state.

Troops are now rolling into Washington and the anxious people of this city breathe easier.

I return a letter which Sadie sent to my address and which was forwarded to me at this place after going to Keokuk as one from Sam was.

See that PM $^{59}$ and tell him you are authorised to receive and open my letters in my absence. We got your letter last night written the day after I left

${ }^{58}$ Samuel Jordan Kirkwood, governor of Iowa 1859-1863, 1876-1877, U. S. Senator 1866-1867, 1877-1881, was also Secretary of Interior under President Garfield, 1881-1882. Kirkwood issued a call for Iowa troops April, 1861.

${ }^{5}$ Richard McAllister held office until May, 1861. 
Sadie is still at the Resides \& very well

Affectionately yours

Saml R. Curtis

My dear wife

[Washington] Sunday Apl 28, 1861

Yours of the 20th giving me news of the progress of the volunteering was duly received

The probability is, the required regiment was made up in a few days, and a large reserve remains ready for service if called for. It is easy now to get volunteers and I wish they could be enlisted "during the war" instead of being called out for temporary purposes

Mr. Reside [?] arrived home last night from Arkansas. He says the whole South is united now and fears they will soon attack Washington. He says they have negroes regularly enrolled and mustered in companies and that Jefferson Davis is at Richmond tonight.

Now that we have about 14 thousand troops here and more coming every day we feel rather pleased to hear they are concentrating in this direction where they can be properly met. General Scott is laboring incessantly and his aids also seem busy in keeping pace with the mighty movement surrounding them. A detachment of the N. York regiment which had been left came up the Potomac today; so we now have two routes open, and our regiment (you see I claim kindred) has the right to claim the honor of opening both routes to the Capitol. The 7 th is the pet of the City and Country and well it may be, for it is eligently equipped and very perfect in drill.

Govr Grimes ${ }^{60}$ is here. He does not tell me what for but Sam writes me that the Burlington people are trying to get Burlington made the rendevous and he may have come here for that purpose. If it be true, it is a small potatoe business. I recommended the Governor to rendevous the troops at Eddyville so they could readily move East by Burlington or South East by Keokuk-Or act against any

${ }^{\circ}$ U. S. Senator James W. Grimes, governor from 1854-1858. 
Missouri raid on the West part of our Missouri boundary. ${ }^{61}$ When I arrived here I found they had directed the muster at Keokuk where it is easily moved but not quite so convenient in all respects. I told the Adjutant General my views which were of course Strategic and properly approved; but so far as the officers here are concerned they say they will defer the matter entirely to the Governor who may be persuaded to change but I trust not in the face of my suggestions.

I have been using my influence to procure a movement down the Mississippi and a large amount of Commissary stores were today ordered to Cairo. There are now more troops en route for this City than necessary and as soon as the crisis is passed here I think we may expect more interesting events on the Mississippi where I hope to be posted. The Iowa troops if not already under way to this city may therefore expect to serve in the West; but this is mainly conjecture on my part, being predicated on the fact stated to me by those leading the army that we are sure to have more here than we need if all arrive who are within a few days march of us.

I think the rebils [sic] will recoil before the forces assembling here, but Mr. Reside thinks they will come directly in front of Washington, and commence bombarding the city. A few days will tell the story for I trust we are becoming so strong that if they do not come to us we can go forward to meet them and it would be far better to keep the war in the Seceeded States.

I expected the Resides with Sadie to go with me to church today but a rain came up at the hour and they did not come. I went up to see the Adjutant General in regard to Iowa troops, and he said no tiding from the Governor had yet been received. If the Governor is in Keokuk say this to him, and it would be well to add that the Adjutant General $^{62}$ and Col. Culum Aid to the Lieut. General

${ }^{61}$ The Burlington \& Missouri Railroad was open to Ottumwa, and the Keokuk and Fort Des Moines Railroad was at Eddyville. The use of the cars was undoubtedly what Curtis had in mind.

"Lorenzo Thomas, graduate of West Point, 1823, served as Assistant Adj. Gen. from 1838 to 1858, except for a period of active duty during the Mexican War. In charge of the Adj. General's office in March, 1861, he was appointed to position in August. Following 1863 he was but nominally in charge of the office. Figured in the Johnson-Stanton quarrel and impeachment proceedings. 
assured me they would make no change of orders in regard to the location of the troops without Consulting me. I would also suggest, that as far as convenient, the Government put the troops in buildings furnishing straw beds (single) for the men to lay on. I think it would be proper for our troops as far as possible to have these conveniences; but at the same time they should learn to use the smallest possible amount of equipment.

I am told here that I am named for Commander of the regiment. I would be pleased to be so elected but hope if I am they will have a first rate Lieut Col for I must attend the next Congress to act on the Military Committee where my services are considered of great importance to the army. My feet are sorer this evening than at any time although I have done very little walking today. I have not yet found time to get over to George Town although I have started twice for that purpose.

Sadie is in good health and spirits but Mr. Reside seems so anxious he disturbs the equinimity of the family $\mathrm{He}$ talks of taking them out of the City and if he does I shall of course make some other disposition of Sadie. Kiss dear little Carrie for $\mathrm{Pa}$ and believe me ever affectionately yours

Saml R Curtis

\section{My dear wife}

Washington May 1, 1861

I am very glad to receive my clothes by S. Rankin Esq who arrived safely last night. I had really become rather shabby in my feelings if not in appearance.

I will now be able to dress up when I go to call on friends. I think you acted very properly in not sending the trunk. There is no [sic] doing much with papers these times. When the crisis is over here I will go direct home so I can take up the papers about as I left them. The extra cession of Congress will not last long so it may be I can be at home a considerable portion of the summer. I remain attached to the Seventh New York Regiment of course doing as I please but apparently very populer in the regiment. 
I shall at the same time attend to our Iowa matters as carefully as possible. James' papers were sent forward day before yesterday. Papers for John St_—us [?] were ordered yesterday. I suppose Howels P.O. papers were sent some days ago but the matters of Bogata is not yet acted on. I will write Howell as to that very soon. ${ }^{63}$

I was very much vexed to find that a man by the name of Taylor of Ohio has been appointed Register at Omaha. I have not yet seen the President but feel like giving him my mind on the subject.

The President has not as much Sagacity as I could wish. $\mathrm{He}$ is more of a joker than thinker.

I have just received and read yours of the 25th and Henrys of the 18th You were still ignorant of my way of coming. Since we pressed our way through Maryland a great change seems to be coming over the spirit of their dreams. I hope Maryland will persistently decline the honor of being made the slaughter ground for this eventful struggle. It will be a just tribute to the loyalty of Govr Hix [Hicks] ${ }^{64}$ and probably save this Capitol as the Capitol of the republic even after a final seperation [?] of the republic shall be established.

The result in Maryland may be attributed mainly to the prudence energy and success of our landing at Annapolis and successful openning of the way through to Head quarters.

Goodril writes that he wants me to pay Henry Love Tell him I have no means of any consequence now in $\mathrm{N}$ York to draw on and cannot draw till Congress meetsnor then till appropriation can be made So I cannot pay that note. Besides I have got a judgement deferred on a promise to pay which will come upon me in the form of an execution from $\mathrm{Ft}$ Madison if I am not wide awake.

Indeed I am very much embarrassed in regard to several debts and must look out for losses

\footnotetext{
"James B. Howell, succeeded Richard MeAllister as postmaster of Keokuk in May, 1861, served until 1866. Howell later served the unexpired term of James W. Grimes when the latter resigned from the Senate in 1870 .

New Granada, later Columbia, had as its Minister George W. Jones of Dubuque, Iowa. Jones, a Democrat, was certain to be replaced. Howell apparently was in hopes that as an Iowan he was eligible for the appointment.

WThomas H. Hicks, governor of Maryland 1857-1861; U. S. Senator 1862-1865.
} 
Sadie was complaining yesterday, but is generally quite well. I expect to meet her and Miss Mary at 5 at the Presidents grounds where the Seventh N York band is expected to perform

I am very well \& evg-[?]

Affectionately yours

Saml R. Curtis

\section{War Department}

May 7. 1861.

In the absence of regular officers for the purpose the Hon. Col. Samuel R. Curtis of Ioway [sic] late of the U.S. Army, is hereby appointed to muster into the Service of the United States the quota of Militia of the State of Ioway called out under the requisition of the President of the U.S. ${ }^{65}$

$\mathrm{He}$ is authorised to take all steps necessary to equip, provisions, and supply these troops till the officers of the several administrative departments can be ordered to relieve him, until which time he will receive, and govern himself, by the instructions these Departments may give.

Simon Cameron

Secy of War

Head quarters Iowa Volunteers Keokuk May 27. 1861

Genl. L. Thomas

Adt Genl U.S.A.

I wrote you from Des Moines last week saying I had Commenced to muster the 2nd Iowa Regiment. I have now the honor to report that the 1st and 2nd Regiments are here mustered in, and the $3 \mathrm{~d}$ will be here all of this week. ${ }^{66}$

Your orders to Lieut Chambers ${ }^{67}$ having arrived authorizing him to muster the second call, to avoid confusion, I at

\%The call for 75,000 ninety day troops of the state militia was issued by Lincoln April 15. Iowa's quota was one regiment. There was a subsequent call for three year troops several weeks later. Three regiments were quickly formed in Iowa to rendenvous at Keokuk May 20.

${ }^{6}$ The 1st Iowa Volunteer Regiment was for 90 days, and was mustered in May 13. The 2nd Iowa Vol. Regt. was for three years, and was mustered in May 27, the date of this letter.

ש7Probably Alexander Chambers, United States Military Academy 1849, later colonel of the 16th Iowa Vol. Infantry, and an appointed Brigadier General. 
once relinquished to him the remainder of that duty; but he very ungraciously as I think, declines to recognize my mustering, and in the face of my order from the Secretary of war, persists in mustering over what I have mustered. Of course I have protested against this.

Before his order came to muster the 3 year regiments, I had procured books and blanks of you, 2000 muskets and 80 rounds of Cartridges for two reigments, ordered the cartridge boxes for two regiments at Pittsburg, and rallied the whole force required at this place, where Govr Kirkwood has directed me to take temperary command.

I transmit a request made by the Governor and staff, and that my authority may be enlarged \&c recognized at headquarters. If my proceedings be approved, a telgraphic order through me to Lieut Chambers directing his recognition of my acts, would seem necessary to carry forward the complete and early equipment of these troops, and avoid petty conflict of a rightful exercise of discretion. A point so remote as this, must apply to the source of military power, in order to avoid shameful delay. I therefore respectfully request you to direct all the requisite supplies for three regiments (inclusive of what has been sent) to be forwarded as the guns were, without the delay of circuitous requisitions. Send Books and blanks from your office.

Ordinance stores for officers and men for 3 regiments (less 2000 guns and cartridge boxes) and when they are not already prepared, let power be given to procure them.

Quartermasters stores including Knapsacks \& canteens; and where they cannot be obtained directions to procure them.

Commissary stores. I have ample power granted me in this respect by Col Taylor, but have not acted as Lieut Chambers seems to assume that duty.

The Governor has procured some of the supplies here enumerated, but when they can be exchanged or substituted by Government supplies, the State of Iowa will receive back such as may be unnecessary to the General Government. 
Anxious to expedide the enrollment of the Iowa troops with great dispatch, and the least possible trouble to you, let me ask that the duties here invoked be assigned to your asst, Col McDowell, ${ }^{68}$ who assisted in former orders relating to this locality.

I am also authorised to say, two more regiments are enrolled and ready to march to this depot in ten days if it be your pleasure to receive them under the three year call.

I would add that we get good men, and all sorts of provisions are cheaper here than in any part of the country. It is therefore a good healthy rendevous.

\section{Very Respectfully \\ Your Obt Sert \\ Saml R. Curtis \\ Mustering Officer \&c}

Head Quarters 2nd Regiment Iowa Volunteers Keokuk, June 2nd 1861

General Order

No. 3.

The roll calls for duty will be as follows:

Revelie at 5 o'clock a.m.

Breakfast at $6 \frac{1}{2}$ oclock

Surgeons call (For mustering and providing for the sick)

at 7 o'clock

Guard Mounting at 8 o'clock.

Dinner at 12 o'clock M.

Evening Parade at 7 o'clock P.M.

Taps (silence and repose throughout the camp) 10 O'c.

Drill-

For convenience of supervision while the companies are in quarters, the Regimental and Company drills will habitually be conducted in the portion of the city limits north of Main street except on Sundays and Saturday afternoons. Company and squad drill to be from $5 \frac{1}{2}$ o'clock to $6 \frac{1}{2}$ A.M. and from $8 \frac{1}{2}$ to 11. A.M. Company drills will again commence at $3 \frac{1}{2}$ P. M. and be merged into regimental

esIrvin McDowell, United States Military Academy 1834, Asst. Adjt. General 1847-1861, later a major general of volunteers, 1862. 
drill at 4 P.M. to be dismissed at the discretion of the Officer Commanding. The Field and Company Officers will personally supervise and direct the drills and all the members of the regiment are expected to dilligently study and practice the profession they have adopted.

The manual of arms will habitually be that of the musket or heavy infantry as shown in the infantry Tactics of May 1 st 1861 page 74 to 88 . When for change a commander may desire to teach the light infantry or rifle manual he shall give the caution "As Riflemen."

By order of Saml R Curtis, Co Comdg. N. P. Chipman Adjutant

Head Quarters 2nd Regt. Iowa Volunteers

Keokuk June 3. 1861

Hon S Cameron

Secy of War

Dr Sir

It is needless for me to suggest that as far as possible appointments should be made from the graduates of the Military Academy to military positions. Your recent order to Governors in this respect will do good. The constitution of this State intervenes and requires every officers election Still in the volunteers the experienced or educated men who are otherwise qualified are generally preferred. I received the unaminous vote of the first 3 year regiment for Colonel. But beyond this I respectfully suggest that appointments to a prospective increase of the army should be made from those who have become enrolled and now show fitness and fidelity worthy of consideration. Such a rule may have exceptions, but it would help secure good material and give encouragement to those in the service.

I find most of those who fail before the people are pressing their claims before the Department and I very much doubt the propriety before appointing such men to a prospective increase of regulars when the chances are you will neither secure better officers nor better men. You 
have gone so far in the volunteer mode of enrollment, and been so successful, I think the [illegible] way will be to mold the volunteers into regulars \& retain such as you need as long as circumstances require.

The difference between a volunteer for 5 years and a regular for 5 years would only be in the mode of appointing officers, and this can be so modified as to secure proper places to all the educated material our schools afford.

$$
\begin{aligned}
& \text { Very Respectfully } \\
& \text { Yr Obt Servt } \\
& \text { Saml R. Curtis }
\end{aligned}
$$

[copy]

Keokuk Ioway [sic] June 5. 1861

Major Ebenezer S. Sibley

\section{Acting Quarter Master Genl}

Dr Sir

You will recollect that I was authorized by the Secretary of War to procure an outfit for the Iowa troops. The arms and accoutraments have been procured and bills for transportation are presented. ${ }^{69} \mathrm{I}$ have turned the main business over to Lieut Chambers mustering officer but I have made some necesary purchases which I think will be aproved and estimate necessary funds as follows

For transportation of arms 500.00

Accoutraments 360.00

Storage 50.00

Purchasing of Hay, Straw, Shoes \&c.... 250.00

Traveling Expenses 760.00

$\$ 1320.00$

You will oblige me by placing this sum subject to my check in the city of N. York.

\section{Very Respectfully Your obt Servt Saml R Curtis}

"The accoutrements included cartridge boxes, bayonet scabbords, and waist bands. As early as May 20 they were reported to have left Pittsburgh. No tents were reported available in Washington, according to a report of Curtis in the 
Keokuk Iowa June 8. 1861

Hon S. Cameron

\section{Secy of War}

This will be handed to you by our mutual friend Hon Jno. W. Rankin $;^{70}$ who is especially charged with dispatches relating to the equipment of Iowa troops. You will do me a great favor by lending him your reasonable influence, and also do yourself justice towards the bearer your most devoted and efficient Iowa friend.

I will soon have the best drilled regiment in the service: and must have RIFLED muskets for them at an early day, if possible. We have 3 full regiments here and could in ten days have ten more.

The only trouble is equipment which I hope to expedite through Mr. Rankins and Col. McAlisters efforts at Head Quarters.

\section{Very Respectfully \\ Your Obt Sert, Saml R. Curtis}

\section{Head Quarters 2nd Regt Iowa Vols} Keokuk Iowa June 8. 1861

Col J. W. Ripley

Acting Chief Ord Dept.

Dr Sir

I secured the guns and cartridge boxes for two Iowa regiments and hope before this time further supplies from your department have in some way been forwarded as we now have 3 Regiments assembled at this place.

My special desire is to secure rifled muskets in exchange for the smooth muskets as far and as soon as possible. Other states have been more fortunate perhaps because they have been more officious; but my people expect my influence to be at least equal to that of most [?] who never "Set a squadron in the field" or had the honor of

Keokuk Daily Gate City May 15. On May 21, 2000 muskets arrived, reportedly from the St. Louis Arsenal, all smooth bores, altered to be fitted with percussion caps. These inferior weapons, the Gate City observed, "will answer for drilling and other purposes and are a heap sight better than nothing."

${ }^{70} \mathrm{~A}$ former law partner of Curtis. 
a personal acquaintance with most of the Government officers.

This will be handed to you by a special friend Hon J. W. Rankin who goes East to assist in collecting and forwarding our Iowa equipment. Let us have at least my Regiment armed with our best patterns of muskets.

Very respectfully

Your obt Servt

Saml. R. Curtis

Col 2d Regt Iowa Vols

[copy]

Genl L. Thomas

Adt Genl U.S.A.

Dr Sir

Three regiments each over a thousand strong are now assembled here, and earnestly and anxiously awaiting Complete equipment. I command the 2nd (The first for 3 years) and it is already pretty well advanced in company and battalion drill.

By your order No. 15 there is allowed to each regiment one asst quartermaster, one asst. surgeon, and 2 lietuenants to a company. The regiments are much larger than those we had in Mexico, and I think we will need the same number of officers we had then, i.e. 2 surgeons, 1 quartermaster 1 Commissary and 3 Lieutenants to each company. The quarter master and Commissary may both be detached [?] from the Lieutenants and so of the adjutant if we have 3 Lieutenants to the company.

I shall write the Comissary department on the subject of varying the ration to suit the varied localities of our army, which if necessary I hope you will favor as our present ration is not adapted to the abundance of wholesome and cheap food found in the Mississippi Valley

Very Respectfully

Your obt Servt

[copy]

Saml R. Curtis 
Keokuk June 9th. 1861

Genl N. Lyon ${ }^{71}$

\section{Dr Sir}

Yours of the 6 th is received. All the Iowa Call 3 regiments each over 1000 strong are here. Two thousand muskets and 40 rounds of cartridges are distributed, I am ready to cooperate therefore although as yet we lack tents haversacks and knapsacks and many other things which we hope soon to receive. But in case of immurgency [sic] command me and I will respond promptly.

In the mean time I am keeping myself advised of movements on the Missouri side. The Unionists are greatly in the ascendency in Clark county; but at Aetna in the edge of Clark and Scotland there is a nest of traitors that ought to be blown up. Yesterday they had a Union meeting called there and some 200 unarmed Union men assembled to hear a speech. The traitors to the number of 100 came armed with rifles shot guns \&c. guns loaded and prevented the speaking. The yhave a Company commanded by one Capt Duil [?] and the carry the Secession flag There is also a flag on a high pole in Aetna-red white and redand a blacksmith manufacturing knives and other weapons. It is a little town of about 200 people. There is also a company of traitors about 40 strong at Edina The Union men want some kind of military or civil authority with [a few] arms to [go and destroy the rascals.-crossed out] put the rascals down LaGrange or Alexandria would be a good point for mustering a force and there are thousands of Union men anxious to be enrolled: but they have no color of Law while the traitors are organizing under the State law.

Something is needed to countervoid that develish Legislative treason. [by charging Iowa with a breach of state soverignty-crossed out]

If you had a little force at Alexander or Legrange it could be easily Augmented from here so as to operate

\footnotetext{
"Nathaniel Lyon, United States Military Academy, 1841, engaged in the Seminole wars, on the coast in California and stationed in Kansas prior to the outbreak of war, was an ardent northern sympathiser. Appointed in charge of the St. Louis Arsenal in February, 1861, he was made a brigadier general in charge of Union forces in St. Louis in May. He was killed in August, 1861, in the bloody battle of Wilson's Creek,
} 
effectually with the Union men and without any fuss on the score of state interference \& state pride. [The Union men of Clark could easily raise a considerable force ready to be mustered in if you have authority for so receiving force and they want a hand in wiping out the Squad at Aetna.-crossed out] There is a company of 300 Union men ready for organization in Edina and about 200 in Clark willing to fight and anxious for arms to crush out the rascals. I think a few days would be needed to get the rascals together again at Aetna where they might be surrounded ala Camp Jackson.

I am drilling my regiment very hard, and will soon have it in excellent condition as the material cannot be beat. Come up and review us. You will find a hearty welcome, and it will give encouragement to my efforts in advancing organization discipline and drills. [I expect a class mate of mine A Kean will have command [of] the 3d Regiment so you may soon count on fine backing by pretty well drilled troops from Iowa-crossed out]

\section{Very truly yours}

Saml R Curtis

[copy] Col 2nd Iowa Vols

Head Quarters Department of the West, St. Louis Arsenal, June 12th $1861^{72}$

To Col S. R. Curtis

Keokuk, Iowa

A terrible secession movement, headed by Gov. Jackson, has commenced

I want you to come at once, with all the force you can command, to Hannibal, Mo. and move over the road from there to St. Josephs and put down the traitors every where on both sides of the road, and if possible, strike down upon Lexington

N. Lyon

Brig Gen U.S. Vols

[copy]

Commanding

${ }^{72}$ General Lyon was on the point of setting out on an expedition up the Missouri River to drive Price and the Southern forces out of the northern portion of the State. 
Col. Curtis-

St. Joseph, June 18, $1861 .^{73}$

Dear Sir: The undersigned, citizens of Missouri, fully aware of the delicate duties enjoined upon you, as the military commander of this post, and feeling a deep solicitude for the preservation of as much peace and quietness among the people in the surrounding country, as the extraordinary circumstances which environ us will allow and in further view of the arrests already made by you ; and that the public mind is greatly excited. Men have left their homes, business of every character is paralized and apprehensions entertained that the arrests made by you, in discharge of your military duty are to be indiscriminate and against those who entertain southern sentiments, as well as those found in armed organization against the Government of the United States. We, therefore, respectfully ask that you will communicate to us your views upon this subject; hoping and believing that it will have the effect of quieting the public mind, and allow the farmers to return to their homes, and quietly attend to their farms and gather their harvest which is now ripe and suffering for the want of reapers.

We have the honor to be, Very Respectfully,

Austin A. King
Silas Woodson
J. M. Bassett,
H. M. Vories,
Jas. Craig
R. M. Stewart

Camp Lyon, Near the City of St. Joseph ${ }^{74}$ June 21, 1861.

Messrs. Austin A. King, and others-

Gentlemen: Your note of the 18th has been received, and I embrace the very first leisure moment to reply there-

\footnotetext{
7sPrinted in the St. Joseph Daily Journal, June 22, 1861.

${ }^{74}$ Tbid. A Confederate flag had been raised in St. Joseph, a Union flag hauled down and torn to shreds; a railroad bridge was discovered on fire, and the suspected parties arrested, found to be secessionists ; two men were arrested and charged with membership in a military drill company marching under the Confederate banner. using swords taken from the government arsenal at Liberty, Missouri. The Secessionist friends in St. Joseph had also secured a hasty Common Council ordinance acsinst the raising of flags in the city, apparently designed to prevent a federal flag from being flown.
} 
to. In regard to my mission here, I have to say that I am sent here by my Government and your Government to support and sustain the supremacy of the constitution and laws of our common Government, the United States of America. Extraordinary efforts have been made to induce our people to embark in a foolish and wicked assault on the Government and laws that protect them. Men are enrolled, mustered, and in arms against their own country, and therefore against the peace of society, and my orders and purpose are to suppress these unnatural belligerants by military force. So far from disturbing peaceable law abiding citizens, it is my desire to protect and shield them from insult, anarchy and oppression. But those who are in arms or hiding, directing and encouraging "secession" and civil war I regard as enemies of our country, and they will be pursued with all calamities of civilized warfare.

It is difficult to distinguish between those who enrolled under former laws with no view of rebellion and those who are recently enrolled with the avowed purpose of cooperating with secession armies, but I will of course endeavor to guard the innocent men when found associated with rebels if they promptly take oath of allegiance, and immediately and publicly withdraw from such associations. While it is my painful duty to carry forward the aims and emblems of National power against persons we have before regarded as citizens and friends, I will rejoice to see them surrender their arms, return to their allegiance and unite with us in sustaining a flag that our fathers unfurled, our country maintains, and the world continues to respect and honor.

I hope we of this generation may be equal to the occasion and transmit the blessings of liberty to succeeding generations.

Uniting with you in sympathy with those who innocently suffer from the accidents and havoc of war, I am, very truly and respectfully

Your ob't Servant, Sam'l R. Curtis

Colonel Commanding 
Copyright of Annals of Iowa is the property of State of Iowa, by \& through the State Historical Society of Iowa and its content may not be copied or emailed to multiple sites or posted to a listserv without the copyright holder's express written permission. However, users may print, download, or email articles for individual use. 